\title{
Identifikasi Peran dan Koordinasi Pemangku Kepentingan Terhadap Pengembangan Sarana dan Prasarana di Atraksi Wisata Menara Siger, Kabupaten Lampung Selatan
}

\author{
Krisna Sella1, Mohamad Yusuf² \\ Affiliation \\ 1,2 Program Studi S1 Pariwisata, Fakultas Ilmu Budaya, Universitas Gadjah Mada \\ Correspondence \\ Mohamad Yusuf. Program StudiS1 Pariwisata, Fakultas Ilmu Budaya, Universitas Gadjah \\ Mada. Jl. Sosio-Humaniora, Bulaksumur, Sleman, Yogyakarta.Email: myusuf@ugm.ac.id.
}

\begin{abstract}
Menara Siger is not only perceived as a tourist attraction, but it is also consider ed as an icon of Lampung Province. Located in Bakauheni, South Lampung Regency, Menara Siger is managed by different stakeholders. The objective of this research is, therefore, to identify stakeholders who are involved in the management of the Menara Siger, and to investigate the role of each stakeholders, particularly to the development of facilities an d infrastructure. This is a qualitative descriptive research, which uses an inductive approach. The data collection methods include interviews, observation and lite rature study. This study finds that there are stakeholders that are identified as be ing the most dominant in roles, namely the local government, non-governmental or gan izations and industries. These three stakeholders play more dominantly than the others, due to their authority, impact and concerns. Furthermore, eachstakeholderhas its own problems, however, there attempt to do coordination to each other. This study shows that the problem that occurs is predominantly related to early-stage coordination that does not work effectively, for instance, limited discussion and communication between stakeholders, the role of each stakeholders are not optimal enough and decision making processes are considerably not working properly because the lack of stakeholders involvement. There are several overlapped roles and interests of stakeholders caused by government intervention who roles as the one of the most dominant stakeholders.
\end{abstract}

Keywords: Siger Tower; Stakeholders' Coordination; Tourism Facilities and Infrastructure.

Article Information

Submitted 18 Juli 2020 | Revised 25 September 2020 | Accepted 28 January 2021

Recommended Citation: Sella, K., Yusuf, M. (2020). Identifikasi Peran dan Koordinasi Pemangku Kepentingan Terhadap Pengembangan Sarana dan Prasarana di Atraksi Wisata Menara Siger, Kabupaten Lampung Selatan. Jurnal Pariwisata Terapan, 4(2), 130-146. https://doi.org/10.22146/jpt.60439

Copyright (C) 2020 bythe author(s). This article is published by Universitas Gadjah Mada, Indonesia under the Creative Commons Attribution (CC BY 4.0) license. Anyone may reproduce, distribute, translate, and create derivative works of this article (for both commercial and noncommercial purposes), subject to full attribution to the original publication and author(s). The full terms of this license may be seen at http://creativecommons.org/licenses/by/4.0/legalcod 


\section{Pendahuluan}

Dalam industri pariwisata, pemangku kepentingan memegang peran penting bukan hanya dalam perencanaan, namun juga dalam implementasi dan kontrol pengelolaan pariwisata (Turker, dkk 2016: 118; Swarbrooke 1999: 17). Apabila pemangku kepentingan berhasil menjalankan perannya sesuai dengan fungsi dan wewenangnya, maka pengembangan pariwisata tentunya akan berjalan dengan optimal dan menghasilkan dampak positif yang akan dirasakan bukan hanya bagi pemerintah pusat dan daerah, namun juga bagi masyarakat setempat (Manish, 2010; McKercher, 2003).

Pemangku kepentingan utama dalam pengembangan pariwisata di daerah adalah Dinas Pariwisata sebagai perpanjangan tangan pemerintah pusat dan pemerintah daerah. Dinas Pariwisata memiliki fungsi dan wewenang dalam mengembangkan potensi wisata di daerahnya, dan tentu harus mempunyai perencanaan yang matang dalam mengembangkan pariwisata serta menjalankan kebijakan pariwisata secara optimal. Namun demikian, Dinas Pariwisata tentu saja seharusnya juga mampu menciptakan koordinasi dan kolaborasi dengan pihak-pihak kepariwisataan.

Provinsi Lampung memiliki atraksi wisata yang unik, yaitu bangunan Menara Siger, dan berdasarkan Keputusan Gubernur Lampung No: G/214/B.III/HK/2009 telah ditetapkan sebagai ikon pariwisata daerah. Menara Siger ini menjulang setinggi 32 meter, berdiri di atas ketinggian Bukit Gamping 110 meter di atas permukaan laut. Sesuai dengan namanya, menara dengan warna dominasi kuning dan merah ini memiliki bentuk menyerupai Siger, yaitu mahkota adat pengantin wanita di Lampung.

Pembangunan menara ini digagas oleh Gubernur Lampung Sjachroedin ZP pada awal tahun 2005, dengan bantuan arsitek Ir. Anshori Djausal MT. Dengan teknik pembangunan menggunakan sistem ferrocement ${ }^{1}$, bangunan ini diyakini tahan terhadap terpaan angin dan guncangan gempa. Menara Siger diresmikan pada tanggal 30 April 2008. Di Kawasan Menara Siger terdapat sarana dan prasarana yang mendukung kegiatan pariwisata. Selain itu, Menara ini juga dilengkai dengan museum yang berisi informasi tentang sejarah Provinsi Lampung.

Dalam pelaksanaan pengelolaan Menara Siger Lampung, Dinas Pariwisata Provinsi Lampung mempunyai Unit Pelaksana Teknis Daerah (UPTD) Pengelolaan Kawasan Wisata Menara Siger yang diatur dalam Peraturan Gubernur (Pergub) Lampung No. 10 Tahun 2020 tentang Pembentukan, Organisasi dan Tata Kerja Cabang Dinas dan Unit Pelaksana Teknis Daerah pada Perangkat Daerah Provinsi Lampung. Meskipun demikian, masih terdapat beberapa potensi konflik dan kendala dalam manajemen pengelolaan yang dialami oleh pihak pengelola.

Berdasarkan observasi awal melalui ulasan Google, pengunjung merasa bahwa keadaan sarana dan prasarana di Menara Siger dinilai kurang memadai dan tidak ada perawatan yang berkelanjutan oleh pihak pengelola. Berikut adalah beberapa tanggapan pengunjung yang diambil melalui ulasan Google mengenai Menara Siger.

\footnotetext{
${ }^{1}$ Ferrocement: material ini mudah dijumpai dan dapat diproduksi secara masal serta memiliki kekuatan yang tidak kalah dengan baja maupun material lainnya. Struktur ferrocement ini juga mudah dikerjakan, me to de pembangunannya sangat sederhana serta memiliki keunggulan dari segi biaya.
} 
Beberapa pengunjung beranggapan bahwa sarana dan prasarana yang tersedia pada atraksi wisata Menara Siger kurang terawat. Sebagai ikon pariwisata di Provinsi Lampung, Menara Siger seharusnya dikelola dengan baik, karena mempunyai potensi untuk mendatangkan wisatawan. Akan tetapi, sampai saat ini perhatian pemerintah daerah terhadap pengembangan daya tarik wisata di Menara Siger dinilai masih minim.

Observasi lapangan yang dilakukan oleh peneliti menunjukkan bahwa terdapat kerusakan fisik yang relatif parah pada bangunan Menara Siger, serta terdapat pula sarana atraksi wisata yang tidak dapat berfungsi sebagaimana mestinya, seperti Jam Matahari (Sundial). Selain itu, peneliti juga menemukan adanya kegiatan vandalisme di dalam bangunan Menara Siger.

Masalah sarana dan prasarana yang menjadi kendala dalam pengembangan Menara Siger adalah salah satu masalah yang muncul di permukaan karena akar permasalahan sebenarnya terdapat pada koordinasi antar pemangku. Dalam sektor pariwisata yang kompleks, kebutuhan koordinasi merupakan suatu kebutuhan yang mutlak, karena tanpa koordinasi masing-masing pemangku kepentingan memiliki tujuan yang berbeda-beda sehingga kemungkinan adanya potensi konflik yang mengakibatkan kekacauan semakin besar (Lemmetyinen, 2010; Alonso dan Nyanjom, 2017; Freeman dan McVea, 2001).

Permasalahan lainnya yang muncul yaitu permasalahan sengketa lahan di Menara Siger pada tahun 2014 yang menjadi bukti adanya masalah dalam hubungan dan proses koordinasi antar pemangku kepentingan yang terlibat di dalamnya. Oleh karena itu, studi mengenai peran dan koordinasi pemangku kepentingan dalam mengembangkan Menara Siger, khususnya dalam pengembangan sarana dan prasarana dirasa penting untuk dilakukan.

Tujuan dalam penelitian ini adalah untuk mengidentifikasi peran yang dijalankan oleh masing-masing pemangku kepentingan yang terlibat dalam pengembangan sarana dan prasarana di Menara Siger. Selain itu, berdasarkan permasalahan yang diangkat dalam penelitian ini, akan dianalisis pula mengenai upaya yang dapat dilakukan agar koordinasi antar masing-masing pemangku kepentingan menjadilebih baik.

\section{Landasan Teori}

Freeman dan McVea (2001: 46) menjelaskan bahwa pemangku kepentingan adalah sekelompok orang atau individu yang dapat mempengaruhi dan dipengaruhi oleh tujuan yang ingin dicapai. Sementara itu, Donaldson dan Preston (1995: 69) memaparkan bahwa suatu kelompok/organisasi dapat memenuhi syarat sebagai pemangku kepentingan apabila mempunyai kepentingan yang sah dan mendapatkan manfaat dalam aspek kegiatan suatu organisasi/aktivitas. Dalam konteks pariwisata, tourism stakeholders concept atau konsep pemangku kepentingan dalam pariwisata menganggap destinasi sebagai suatu media pembentukan jaringan dan hubungan dari berbagai individu atau kelompok yang terlibat dengan kepentingannya yang berbeda-beda, dan dapat saling mempengaruhi atau dipengaruhi dampak baik maupun buruk dari pariwisata, serta memastikan tujuan yang akan dicapai yaitu keberlanjutan terhadap destinasi dalam jangka panjang (Hieu \& Rašovská, 2018: 92; Kurnianto, 2019: 11). Kemudian Donaldson dan Preston (1995: 69) menggambarkan “Stakeholders Model” pada Gambar 1. 


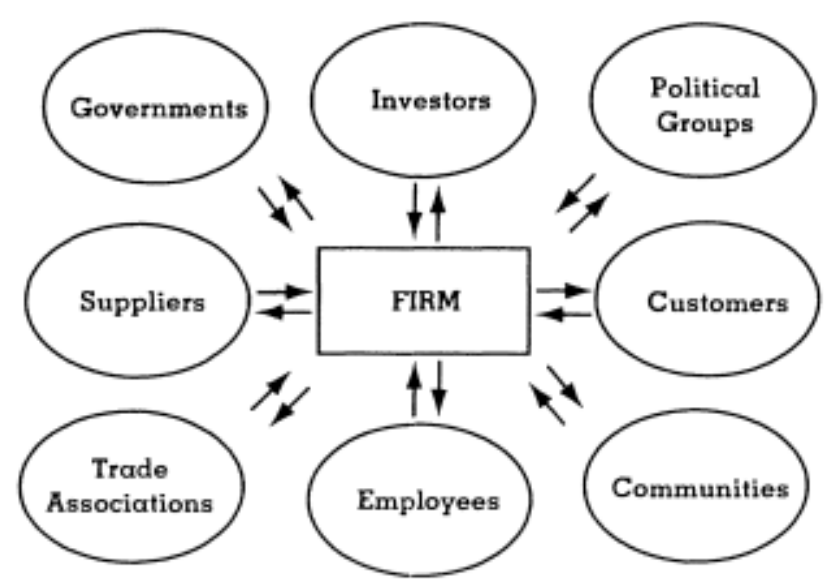

Gambar 1. Model Pemangku Kepentingan Donaldson dan Preston (1995) (Sumber: Donaldson dan Preston, 1995:69)

Berdasarkan model pemangku kepentingan yang dipaparkan oleh Donaldson dan Preston (1995: 69) di atas, terdapat delapan pemangku kepentingan yang digambarkan saling terhubung oleh anak panah yang menghadap dua arah. Semua hubungan pemangku kepentingan digambarkan dalam ukuran dan bentuk yang sama serta tidak adanya pihak yang diistimewakan. Dengan kata lain semua kedudukan pihak sama dan saling ketergantungan.

Lemmetyinen (2010: 10) melihat bahwa destinasi wisata bukan hanya sebuah tempat, melainkan sebuah panggung untuk aktor (dalam konteks ini adalah pemangku kepentingan) yang terhubung satu sama lain, agar dapat berinteraksi dengan bertujuan untuk menyediakan produk pariwisata. Dalam pandangan Turker, dkk (2016: 418), pemangku kepentingan dalam sebuah destinasi wisata dapat diidentifikasi sebagai wisatawan (sisi permintaan), pelaku usaha pariwisata (sisi penyedia), dan tuan rumah (masyarakat sekitar dan lingkungan). Turker, dkk (2016: 418) selanjutnya membagi pemangku kepentingan dalam pariwisata menjadi lima kategori utama: pemerintah, pengunjung, masyarakat lokal, industri pariwisata, dan sektor lainnya/lembaga nonpemerintah/non-governmental organization (NGO). Selain kelima kategori utama yang disebutkan, masih terdapat pula pemangku kepentingan lain yaitu akademisi dan media (Swarbrooke, 1999: 17).

Berdasarkan pemaparan mengenai pemangku kepentingan pariwisata, penelitian ini menggaris bawahi bahwa pemangku kepentingan dalam pariwisata, sejatinya merupakan individu dan/atau kelompok yang terdiri dari kategori-kategori meliputi pemerintah, pengunjung, masyarakat lokal, industri pariwisata, lembaga nonpemerintah/nongovernmental organization (NGO), akademisi dan media yang memiliki keterlibatan dan saling bergantung dengan permasalahan/isu pariwisata sebagai fokus penelitian/kajian, serta dapat mempengaruhi dan dipengaruhi oleh segala kegiatan untuk pengembangan dan pembangunan pariwisata.

Tentu saja, masing-masing pemangku kepentingan mempunyai peran dalam pembangunan pariwisata. Peran diartikan sebagai ekspektasi bersama dan menjelaskan perilaku yang bersifat normatif (Biddle, 1986 dalam Aloso \& Nyanjom, 2015: 3). Lebih lanjut, peran mencerminkan sikap, norma, negosiasi, tuntutan kontekstual, dan tuntutan pada situasi yang berkembang, didasarkan pada pemahaman individu/pemangku kepentingan (Aloso 
dan Nyanjom, 2015: 3). Setiap peran dapat membawa berbagai sikap karakteristik, emosi atau tindakan. Sehingga studi ini menggarisbawahi bahwa peran adalah perilaku/tindakan, sikap karakteristik, negoisasi, tuntutan pada situasi kontekstual yang didasari pada pemahaman masing-masing pemangkukepentingan dan diatur secara normatif.

Dalam pandangan Turker, dkk (2016:418), pemangku kepentingan dalam sebuah destinasi wisata dapat diidentifikasi sebagai wisatawan (sisi permintaan), pelaku usaha pariwisata (sisi penyedia), dan tuan rumah (masyarakat sekitar dan lingkungan). Turker, dkk (2016:418) selanjutnya membagi pemangku kepentingan dalam pariwisata menjadi lima kategori utama: pemerintah, pengunjung, masyarakat lokal, industri pariwisata, dan sektor lainnya/lembaga nonpemerintah/non-governmentalorganization (NGO). Selain itu, terdapat akademisi dan media (Swarbrooke, 1999).

Menurut UNWTO (2013:20), yang dikutip oleh Kurnianto (2019:12), pemerintah adalah pemangku kepentingan yang diwakili oleh lembaga/institusi resmi dan mempunyai kompetensi dalam pariwisata yang bertugas untuk membuat kebijakan, strategi, arahan dalam memfasilitasi pengembangan pariwisata dan mengawasi implementasi serta mengevaluasi kebijakan/strategi yang sudah dikeluarkan. UNEP dan WTO (2005) menyatakan bahwa tourist atau pengunjung adalah orang-orang yang melakukan perjalanan ke wilayah atau tempat yang berbeda diluar dari lingkungan kebiasaan mereka untuk tujuan pribadi atau bisnis/professional.

Sama halnya, Gunn dan Var (2002:20) dan Narendra (2018) menjelaskan bahwa masyarakat lokal adalah penduduk yang tinggal di wilayah sekitar destinasi wisata yang terdampak langsung maupun tidak langsung terhadap pengembangan pariwisata. Selanjutnya berdasarkan UU No 10 Tahun 2009 Tentang Kepariwisataan pasal 1, industri pariwisata adalah kumpulan usaha pariwisata yang saling terkait dalam rangka menghasilkan barang dan/atau jasa bagi pemenuhan kebutuhan wisatawan dalam penyelenggaraan pariwisata. Lembaga nonpemerintah/lembaga swadaya masyarakat (non-governmental organization) adalah sebuah lembaga yang bersifat mandiri, swasta, serta bukan lembaga untuk mencari keuntungan melainkan untuk meningkatkan kualitas kehidupan di berbagai sektor (Lewis, 2010:3). Akademisi dalam pariwisata berkontribusi untuk meningkatkan pengetahuan yang dapat memaksimalkan dampak positif dari pariwisata terhadap pemangku kepentingan yang lain (Ellitan dan Anatan, 2009). Selain itu, pariwisata juga sangat tergantung pada media karena sebagian besar informasi mengenai preferensi perjalanan wisata digunakan oleh calon wisatawan melalui media (Kumar, 2014:189).

Setiap pemangku kepentingan tentu saja memiliki perbedaan dalam pemahaman ruang lingkup serta dalam tujuan pelaksanaan kerjanya. Untuk itu, koordinasi merupakan bagian yang sangat penting dalam pembentukan suatu hubungan atau jaringan. Hieu \& Rašovská (2018:94) menyatakan bahwa:

\footnotetext{
"Fungsi dasar dari konsep koordinasi dalam pariwisata adalah hubungan dan kerjasama antar pemangku kepentingan yang memiliki perbedaan kepentingan dalam suatu destinasi, untuk menciptakan kualitas produk dan memperkenalkan imejdari suatu destinasi, untuk memperoleh daya saing yang unggul dan berjangka panjang, serta untuk mencapai tujuan pembangunan berkelanjutan."
} 
Lebih lanjut, Lemmetyinen (2010:10) juga mengungkapkan pentingnya koordinasi bagi pemangku kepentingan pariwisata di suatu destinasi, karena mereka harus berkontribusi dan bekerjasama jika ingin mencapai tujuan.

Definisi koordinasi secara umum dikemukakan oleh Malone (1988:5) bahwa koordinasi merupakan kerjasama antar pemangku kepentingan yang dilakukan berdasarkan kemampuan dan peraturan yang mereka miliki masing-masing, tetapi tetap untuk tujuan yang sama. Lemmetyinen (2010:11) melihat koordinasi dari sudut pandang jaringan sebagai proses pembelajaran bersama yang dapat mengubah struktur dan mempengaruhi pembagian kekuatan di dalamnya.

Dalam konteks pariwisata, Lemmetyinen (2010:12), dan Domański dan Gwosdz (2010) menyarankan untuk membuat dan melaksanakan aktivitas wisata yang dapat memperkuat hubungan antar pemangku kepentingan dan dapat mengendalikan sumber daya, karena saat di destinasi wisata para pemangku kepentingan mempunyai perbedaan fungsi dan kapasitas masing-masing, sehingga koordinasi merupakan sebuah kebutuhan mutlak di dalam industri pariwisata. Selain itu, motivasi utama dari koordinasi biasanya adalah menghindari kesenjangan dan tumpang-tindih berkaitan dengan tugas atau kerja para pihak (Kementerian Pekerjaan Umum dan Perumahan Rakyat, 2016:7).

\section{Metode}

Penelitian ini merupakan penelitian deskriptif yang menggunakan pendekatan kualitatif. Proses penelitian dilakukan selama tiga bulan, mulai bulan Maret sampai dengan bulan Mei 2020. Metode pengumpulan data yang digunakan antara lain menggunakan wawancara terstruktur, observasi non partisipan, studi pustaka, dan dokumentasi. Adapun instrumen penelitian yang digunakan ialah peneliti, pedoman wawancara, alat perekam, kamera, dan alat tulis menulis. Penelitian ini menggunakan metode pemilihan informan melalui purposive sampling. Sumber data dari penelitian ini yaitu: 1)Pemerintah yang diwakili Kepala Unit Pelaksana Teknis Daerah (UPTD) Pengelolaan Kawasan Wisata Menara Siger; 2)Kelompok Sadar Wisata (Pokdarwis) yang diwakili oleh Ketua Pokdarwis Bakauheni; 3)Pelaku Usaha/Swasta (tourism industry) diwakili oleh masyarakat yang memiliki usaha di sekitar Menara Siger (penjual suvenir, penjual makanan); 4) Masyarakat lokal akan diwakili oleh tokoh masyarakat setempat yaitu Sekretaris Desa.

Analisis data yang digunakan dalam penelitian ini adalah analisis model Miles dan Huberman (1994:10) yang meliputi tiga tahap yaitu reduksi data (data reduction), penyajian data (data display), penarikan kesimpulan (conclusion drawing and verification). Tahap pertama adalah mereduksi data. Data yang direduksi dalam penelitian ini meliputi hasil wawancara, catatan observasi lapangan oleh peneliti, jurnal, dokumen, literatur, gambar, dan video dokumentasi, situs, korespondensi elektronik, dan sebagainya. Selanjutnya data yang direduksi akan dituliskan ke dalam beberapa kategori dan sub kategori. Setelah data di reduksi, tahap selanjutnya yaitu penyajian data (data display). Data yang disajikan akan berbentuk deskripsi analitik dan dibagi menjadi beberapa kategori. Data yang terkumpul, diuraikan dalam bentuk pembahasan dan dianalisis berdasarkan teori serta dikaitkan pada penelitian-penelitian sebelumnya. 
Tahap yang ketiga yaitu penarikan kesimpulan (conclusion drawing and verification). Selama tahap penulisan dan penarikan kesimpulan, data harus melewati tahap verifikasi yang dilakukan menggunakan catatan lapangan dan didukung oleh teori-teori yang digunakan dalam penelitian ini. Setelah proses verifikasi, data dianalisis dan dilihat hubungannya satu sama lain sehingga kesimpulan yang diambil dapat dipertanggungjawabkan dan masih dalam konteks tema penelitian. Selanjutnya, data akan dituliskan dalam kesimpulan dan perumusan teori.

\section{Hasil Dan Pembahasan}

\section{Identifikasi Peran Pemangku Kepentingan}

Penelitian ini berhasil mengidentifikasi pemangku kepentingan yang terlibat dalam pengembangan sarana dan prasarana di atraksi wisata Menara Siger, sebanyak tujuh kategori pemangku kepentingan yang mengacu pada Surat Keputusan Gubernur Lampung No:G/493/II.02/HK/2008 tentang Pembentukan Pengelola dan Pengembangan Kawasan Wisata Menara Siger, Surat Keputusan Gubernur Lampung No: G/610/B.IV/HK/2009 tentang Pembentukan Pengelola dan Pengembangan Kawasan Wisata Menara Siger, Peraturan Gubernur Provinsi Lampung No. 10 Tahun 2020 tentang Cabang Dinas dan Unit Pelaksana Teknis Daerah (UPTD) dan hasil wawancara oleh Kepala UPTD Pengelolaan Kawasan Wisata Menara Siger. Para pemangku kepentingan tersebut terbagi menjadi tujuh bagian yaitu:

1. Kelompok pemerintah yang terdiri dari BUMN PT ASDP Indonesia Ferry, Pemerintah Daerah Provinsi Lampung, Dinas Pariwisata dan Ekonomi Kreatif Provinsi Lampung, dan Pemerintah Kabupaten Lampung Selatan;

2. Pengunjung Menara Siger;

3. Masyarakat lokal yang tinggal di sekitar kawasan atraksi wisata Menara Siger;

4. Kelompok industri pariwisata meliputi masyarakat setempat yang mempunyai usaha di bidang akomodasi, makan dan minum, kebutuhan sehari-hari (toko, warung, dll); suvenir, angkutan wisata, permainan anak;

5. Kelompok lembaga nonpemerintah/Lembaga Swadaya Masyarakat (selanjutnya disingkat LSM) yang terdiri dari Kelompok Sadar Wisata (Pokdarwis) Bakauheni, Dewan Pimpinan Daerah Himpunan Pramuwisata Indonesia (DPP HPI) Lampung, Dewan Kesenian Lampung (DKL), dan Environment Tourism \& Social Development Centre /ETSDC.

6. Kelompok akademisi berasal dari Universitas Lampung; dan

7. Kelompok media berasal dari kalangan wartawan kantor berita Antara.

Berdasarkan model pemangku kepentingan Donaldson dan Preston (1995:69) yang telah dikemukakan sebelumnya, semua hubungan pemangku kepentingan digambarkan dalam ukuran dan bentuk yang sama, serta tidak adanya pihak yang diistimewakan dalam kata lain semua kedudukan pihak adalah sama dan saling ketergantungan. 


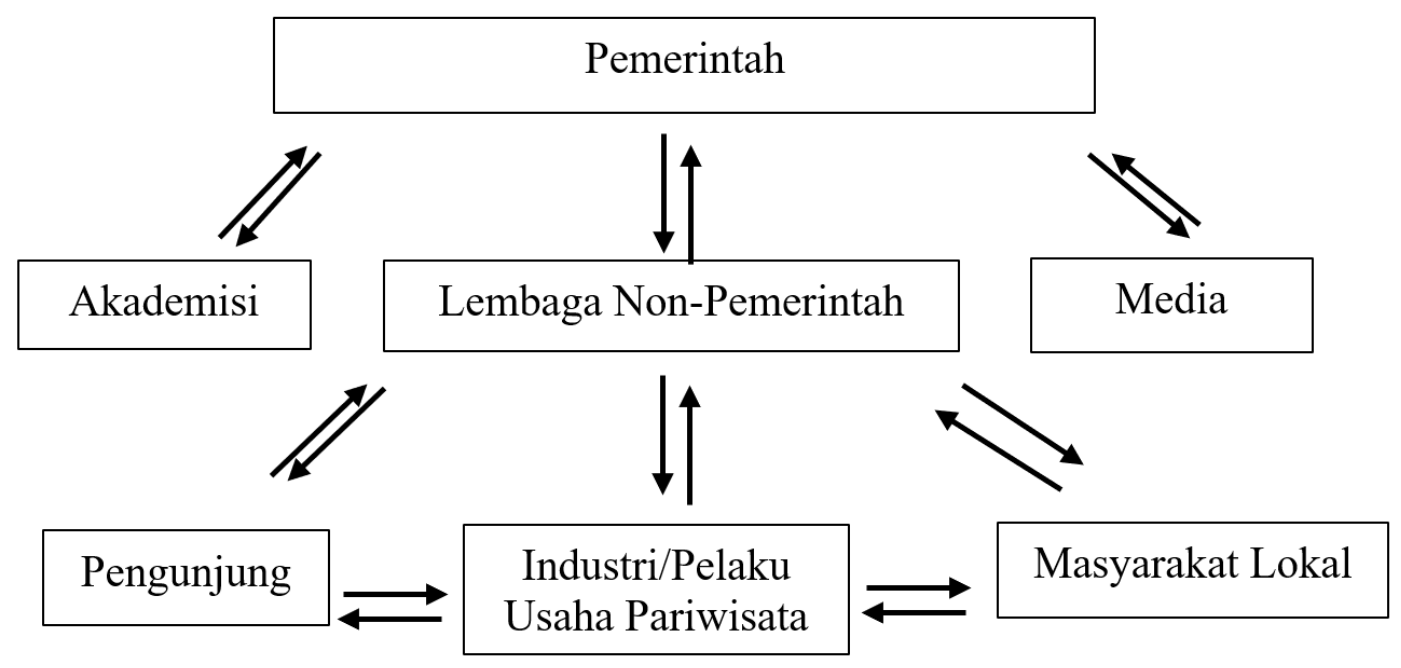
Gambar 2. Hubungan Yang Terjalin Antar Pemangku Kepentingan Berdasarkan Peran Dalam Pengembangan
Sarana dan Prasarana di Atraksi Wisata Menara Siger

(Sumber: Hasil Olah Data Lapangan oleh Peneliti)

Gambar di atas menunjukkan bahwa diantara tujuh kelompok pemangku kepentingan di Menara Siger, pihak pemerintah merupakan pemangku kepentingan yang paling dominan dalam hal pengembangan sarana dan prasarana di atraksi wisata Menara Siger. Posisi pihak pemerintah berada paling atas diantara pemangku-pemangku kepentingan yang lain. Hal ini didasari oleh kewenangan dan perannya sebagai regulator dan fasilitator terhadap segala kebijakan dan peraturan yang menyangkut perencanaan dan pengembangan pariwisata di Menara Siger. Sesuai dengan pemaparan sebelumnya, kelompok pemerintah mempunyai peran inti dalam menentukan arah pengembangan Menara Siger, memfasilitasi kelompok pemangku kepentingan yang lain, mengatur pelaksanaan operasional di Menara Siger, serta perencanaan dan penyediaan terhadap sarana dan prasarana di Menara Siger. Selain itu, dalam penyelesaian masalah terkait sengketa lahan dengan BUMN-PT ASDP Indonesia Ferry, pemerintah memegang peran sebagai pengambil keputusan dan kebijakan.

Gambar di atas juga menunjukkan bahwa hubungan yang terjalin antara pemerintah dengan akademisi dan pemerintah dengan media masing-masing digambarkan melalui anak panah yang menuju dua arah. Hal ini menunjukkan adanya hubungan ketergantungan diantara kelompok akademisi terhadap pemerintah serta kelompok media terhadap pemerintah (Richard, 2002; Rodríguez, 2013). Hubungan ketergantungan ini didasari oleh peran arsitek Menara Siger yang merupakan seorang akademisi di UNILA, serta dilibatkan dalam tim pengembangan dan pengelolaan Menara Siger melalui surat keputusan gubernur. Kemudian peran media terhadap pengembangan sarana dan prasarana di Menara Siger adalah melakukan kegiatan promosi melalui tulisan dan hasil dokumentasi yang dipublikasikan secara online. Dalam menjalani perannya, berdasarkan surat-surat keputusan gubernur mengenai pembentukan tim pengelolaan Menara Siger, akademisi dan media mendapatkan insentif yang dikeluarkan melalui APBD Provinsi Lampung. Namun saat ini, Kepala UPTD Pengelolaan Kawasan Wisata Menara Siger menyatakan bahwa peran pihak akademisi dan media tidak berkelanjutan. 
Selanjutnya, pemangku kepentingan yang mempunyai peran dominan kedua dalam pengembangan sarana dan prasarana di atraksi wisata Menara Siger adalah lembaga nonpemerintah/LSM. Selain menjalin hubungan dengan pemerintah, LSM juga menjalin hubungan dengan pemangku kepentingan yang lain seperti industri/pelaku usaha pariwisata, masyarakat lokal dan pengunjung di Menara Siger. Menurut penuturan Kepala UPTD Pengelolaan Kawaan Wisata Menara Siger, hal ini didasari karena peran LSM sebagai pihak yang memberikan pembinaan dan pelatihan untuk pemangku kepentingan lain khususnya masyarakat dan industri/pelaku usaha pariwisata yang difasilitasi oleh pemerintah. Selain itu, salah satu LSM yaitu Pokdarwis Bakauheni memiliki peran yang besar karena kedudukannya sebagai PTHL di Menara Siger menjadikan intensitas hubungan yang terjalin dengan pemangku kepentingan lainnya semakin tinggi.

Sementara itu, hubungan yang terjalin antara Pokdarwis Bakauheni dengan pengunjung digambarkan dengan dua anak panah. Hal ini menggambarkan adanya ketergantungan antara Pokdarwis Bakauheni (yang berperan sekaligus sebagai PTHL di Menara Siger) dengan pengunjung. Dalam menjalankan perannya sebagai PTHL di Menara Siger, Pokdarwis Bakauheni mempunyai tugas untuk menjaga ketertiban, keamanan, dan kebersihan di Menara Siger. Ketergantungan antara Pokdarwis Bakauheni/PTHL di Menara Siger dengan pengunjung, dipaparkan oleh Kepala UPTD Pengelolaan Kawasan Wisata Menara Siger yang menjelaskan bahwa dana kebersihan di Menara Siger mengandalkan dari hasil penjualan tiket retribusi di Menara Siger, bagi hasil penjualan suvenir, dan uang parkir yang semuanya bergantung pada kehadiran pengunjung. Selain itu, pengunjung juga bergantung pada PTHL Menara Siger sebagai pihak pengelola yang mempunyai tugas untuk menjaga kebersihan, ketertiban serta keamanan. Melalui dana yang pengunjung keluarkan, diharapkan dapat sebanding dengan fasilitas kebersihan, keamanan dan kenyamanan di Menara Siger.

Selanjutnya, pemangku kepentingan yang mempunyai peran dominan dan menempati peringkat ketiga dalam pengembangan sarana dan prasarana di atraksi wisata Menara Siger adalah industri/pelaku usaha pariwisata. Hubungan yang terjalin diantara industri/pelaku usaha pariwisata dengan lembaga nonpemerintah/LSM, masyarakat lokal dan pengunjung, digambarkan pada anak panah yang menuju dua arah. Hal ini menunjukkan bahwa terdapat hubungan yang saling ketergantungan diantara pemangku kepentingan. Hubungan saling ketergantungan yang tercipta diantara industri/pelaku usaha pariwisata dengan pemangku kepentingan lainnya didasari oleh kedudukan industri pariwisata/usaha pariwisata sebagai penyedia usaha barang dan/atau jasa bagi pemenuhan kebutuhan wisatawan dalam penyelenggaraan pariwisata. Peran industri/pelaku usaha pariwisata. Kepala UPTD Pengelolaan Kawasan Menara Siger mengatakan bahwa industri/pelaku usaha pariwisata di sekitar kawasan Menara Siger adalah masyarakat lokal yang mempunyai usaha di bidang akomodasi, makan dan minum, kebutuhan sehari-hari (toko, warung, dll); suvenir, angkutan wisata, permainan anak di sekitar kawasan Menara Siger.

\section{Upaya untuk Memaksimalkan Peran Masing-Masing Pemangku Kepentingan}

Dalam menjalankan peran pemangku kepentingan terhadap pengembangan sarana dan prasarana di atraksi wisata Menara Siger, studi ini menunjukkan bahwa peran yang dijalankan oleh pemangku kepentingan di Menara Siger belum berjalan dengan maksimal karena masih terdapat kendala-kendala yang dialami dan dirasakan oleh para pemangku kepentingan. Kendala-kendala yang ditemukan dalam studi ini, di antaranya sebagai berikut. 


\section{Sengketa Lahan}

Kepala UPTD Pengelolaan Kawasan Wisata Menara Siger mengatakan bahwa kendala yang dihadapi oleh Pemerintah Daerah Provinsi Lampung dalam pengembangan sarana dan prasarana di atraksi wisata Menara Siger adalah terjadinya permasalahan sengketa lahan pada tahun 2014 dengan PT. ASDP Indonesia Ferry. Permasalahan ini muncul ketika pergantian jabatan Gubernur Lampung periode 2014-2019. Penyebab awal permasalahan status kepemilikan lahan di Menara Siger adalah perjanjian lama antara pemerintahan Gubernur Lampung Sjahroedin Z.P sebagai pemrakarsa pembangunan Menara Siger, dengan PT ASDP Indonesia Ferry yang merupakan pemilik lahan di Menara Siger. Isi perjanjian tersebut adalah biaya sewa lahan yang harus dibayarkan Pemerintah Provinsi Lampung sebesar Rp500 juta/tahun kepada PT ASDP Indonesia Ferry selaku pemilik lahan. Namun demikian perjanjian tersebut tidak berlangsung lama. Pihak pemerintahan pada masa $\mathrm{M}$. Ridho Ficardo menyatakan keberatan terhadap biaya sewa lahan Menara Siger, karena pemasukan di Menara Siger tidak berbanding lurus dengan biaya sewa lahannya.

Selain itu, terdapat permasalahan tunggakan uang sewa lahan Menara Siger yang diperkirakan mencapai Rp1 Miliar. Sebenarnya pada masa pemerintahan Sjahroedin Z.P, pemerintah mengharapkan lahan Menara Siger dihibahkan kepada Pemerintah Daerah Provinsi Lampung. Akan tetapi harapan pemerintah saat itu tidak terealisasi sampai masa pergantian Gubernur Lampung periode selanjutnya yaitu M. Ridho Ficardo.

Lebih lanjut, Pemerintah Daerah Provinsi Lampung berinisiatif membentuk tim koordinasi yang terdiri dari Satuan Kerja Perangkat Daerah (SKPD) yang ahli dalam bidang hukum dan advokat melalui Surat Keputusan Gubernur No: G/807/B.X/HK/2014 tentang Pembentukan Tim Koordinasi Penyelesaian Permasalahan Pemanfaatan Menara Siger Provinsi Lampung dan memiliki tugas sebagai berikut:

a. Menyelesaikan permasalahan lahan dengan PT ASDP Indonesia Ferry. menyusun, menyiapkan, dan merumuskan langkah-langkah penyelesaian permasalahan pemanfaatan Menara Siger Provinsi Lampung;

b. Melakukan koordinasi dengan PT. ASDP Indonesia Ferry (Persero) terkait penyelesaian permasalahan pemanfaatan Menara Siger Provinsi Lampung;

c. Melakukan konsultasi dengan instansi terkait baik di tingkat pusat maupun daerah; dan

d. Memberikan saran dan masukan kepada Gubernur Lampung dalam rangka penyelesaian permasalahan pemanfaatan Menara Siger Provinsi Lampung.

Cara penyelesaian oleh Tim Koordinasi Penyelesaian Permasalahan Pemanfaatan Menara Siger adalah merundingkan keringanan tunggakan uang sewa lahan Menara Siger yang diperkirakan mencapai Rp1 Miliar kepada PT ASDP Indonesia Ferry. PT ASDP Indonesia Ferry memutuskan untuk berkoordinasi dengan Badan Pemeriksa Keuangan (BPK) RI Perwakilan Lampung, untuk melihat adanya kemungkinan penggelapan dana. 
Cara kedua yang ditempuh Tim Koordinasi Penyelesaian Permasalahan Pemanfaatan Menara Siger adalah merekomendasikan hubungan kerjasama dengan pihak ketiga, apabila Pemerintah Daerah Provinsi Lampung bertindak bagai pihak yang tetap mengelola Menara Siger. Hal ini dimaksudkan agar biaya operasional Menara Siger tidak dibebankan pada APBD Provinsi Lampung.

\section{Alokasi Pendanaan}

Permasalahan yang kedua, yaitu kendala yang dihadapi Pemerintah Daerah Provinsi Lampung terhadap penggunaan alokasi pendanaan APBD yang dinilai kurang efektif untuk pengembangan sarana dan prasarana di atraksi wisata Menara Siger. Sebagian besar alokasi dana APBD yang dikeluarkan oleh Pemda Lampung untuk Menara Siger digunakan untuk membayar biaya sewa lahan kepada pihak BUMN PT ASDP Indonesia Ferry senilai Rp500 juta/tahun, sehingga biaya operasional Menara Siger seperti biaya kebersihan hanya mengandalkan pemasukan dari pengunjung melalui tiket retribusi, parkir dan lain-lain.

Biaya sewa lahan ditentukan pada awal perencanaan pembangunan Menara Siger diantara pihak Pemda Lampung yang sedang menjabat pada saat itu dan pihak BUMN PT ASDP Indonesia Ferry. Pihak pengelola menilai dana yang dikeluarkan tersebut kurang efektif dalam pengembangan sarana dan prasarana di atraksi wisata Menara Siger.

\section{Perawatan Sarana dan Prasarana}

Permasalahan ketiga yaitu minimnya perawatan sarana dan prasarana yang ada di Menara Siger sehingga mengurangi daya tarik bagi pengunjung. Sarana dan prasarana di Menara Siger dianggap tidak menarik, karena banyak fasilitas yang rusak, usang dan sudah tua.

“...sebenernya aksesnya (ke Menara Siger) gampang banget mba, cuma yafasilitasnya aja si ya kurang dirawatjadinya kurang menarik gitu..."

Ellitan (2009) menggaris bawahi bahwa inovasi sarana prasarana merupakan cara terpenting bagi suatu organisasi guna menciptakan nilai bagi pengunjung dan mencapai keunggulan yang kompetitif, proses inovasi produk tersebut akan berdampak secara langsung terhadap keberhasilan suatu organisasi yang bertujuan untuk meningkatan pendapatan maupun keuntungannya. Dalam hal ini, kebutuhan dalam perawatan sarana dan prasarana di Menara Siger berguna untuk meningkatkan kehadiran pengunjung dan meningkatkan pendapatan maupun keuntungan bagi masing-masing pemangku kepentingan.

\section{Tumpang Tindih Peran}

Permasalahan yang keempat yaitu penemuan yang dilakukan oleh peneliti mengenai tumpang tindih peran dan fungsi pemangku kepentingan di Menara Siger. Esensi fungsi dari Pokdarwis Bakauheni yang juga merangkap sebagai PTHL di Menara Siger, bertentangan dengan tugas pokok dari PTHL itu sendiri. Sejatinya Pokdarwis merupakan kelompok swadaya dan swakarsa masyarakat yang berfungsi sebagai 
mitra pemerintah dan pemerintah daerah (kabupaten/kota) dalam upaya perwujudan dan pengembangan Sadar Wisata di daerah (Makahinda dan Tampongangoy 2015). Namun demikian, pelaksanaan di lapangan menunjukkan ketidakjelasan fungsi pokdarwis.

Penelitian ini menunjukkan bahwa intervensi pemerintah melalui kebijakannya dengan mengangkat Pokdarwis menjadi PTHL di Menara Siger, bertentangan dengan maksud dan tujuan dibentuknya Pokdarwis, sehingga terjadi tumpang tindih tugas dan fungsi (Jordan, dkk., 2012). Permasalahan kelima di atas, kemudian dikonfirmasi oleh Ketua Pokdarwis Bakauheni yang menyatakan bahwa, Pokdarwis yang lain tidak terlalu mengerti tugas dan fungsi dari Pokdarwis, mereka hanya menjalankan tugas sebagai pengelola Menara Siger dan memberikan informasi kepada masyarakat setempat apabila ada informasi dari pemerintah. Kurangnya komunikasi terhadap pemerintah dengan masyarakat lokal juga turut mendasari permasalahan ini.

“...sekarang saya tanya, emang kayak gitu tuh (tugas pokok dan fungsi Pokdar wis me nur ut buku pedoman) masuk pokdarwis tah? seharusnya?..."

Jika merujuk pada pendapat beberapa ahli, keempat permasalahan yang dijabarkan di atas, adalah berkaitan dengan belum maksimalnya peran dari masing-masing pemangku kepentingan karena kurangnya komunikasi diantara para pemangku kepentingan yang menyebabkan pemahaman yang tidak jelas terhadap peranan dari masng-masing pemangku kepentingan (Donaldson dan Preston, 1995; Cooper, dkk., 2004; Carr, 2011). Selain itu, persoalan ini disebabkan oleh terlalu banyak intervensi dan dominasi dari pihak pemerintah sehingga menyebabkan terjadinya tumpang tindih peran pemangku kepentingan. Hal-hal itu dapat memicu terjadinya hambatan terhadap pembangunan dan pengembangan pariwisata di suatu destinasi, sehingga tujuan awal pembangunan tidak tercapai (Alonso dan Nyanjom, 2017; Freemen dan McVea, 2001; Jordan, dkk., 2012).

Berdasarkan kendala-kendala yang dipaparkan oleh penulis di atas, selanjutnya akan dipaparkan analisis mengenai upaya memaksimalkan peranan pemangku kepentingan di Menara Siger. Umumnya kinerja industri pariwisata dinilai dari keuntungan (devisa) dan pertumbuhan kunjungan wisatawan. Namun demikian, dalam praktiknya, harus didasarkan pada kerjasama yang baik antar pemangku kepentingan.

Penelitian ini menunjukkan bahwa pihak pemerintah merupakan pemangku kepentingan yang mempunyai peran paling dominan dalam pengembangan sarana dan prasarana di atraksi wisata Menara Siger dikarenakan kewenangan dan kepentingan yang tinggi (Stange dan Brown, 2013; Tang, 2009). Kewenangan pemerintah terwujud dalam menjalankan perannya untuk menentukan arah pengembangan Menara Siger, memfasilitasi kelompok pemangku kepentingan yang lain, mengatur pelaksanaan operasional dan melaksanakannya di Menara Siger, serta perencanaan dan penyediaan terhadap sarana dan prasarana di Menara Siger. Dalam menjalankan perannya, pemerintah sebaiknya memberikan 'ruang' untuk pemangku kepentingan lainnya agar masing-masing pemangku kepentingan dapat 
memahami peran yang dijalankan. Ruang yang peneliti maksud dapat berbentuk kegiatan sosialisasi, penyuluhan, rapat koordinasi dan lain-lain. Dengan adanya kegiatan-kegiatan ini, besar kemungkinan pemangku kepentingan lebih memahami perannya masing-masing sehingga diharapkan dapat mengimplementasikan perannya secara merata dan berkelanjutan terhadap pengembangan sarana dan prasarana di Menara Siger. Upaya ini dapat diperkuat oleh pemerintah melalui pembuatan produk-produk hukum mengenai aturan kegiatan yang harus diikuti oleh seluruh pemangku kepentingan.

Setelah memahami peran dalam pengembangan sarana dan prasarana di Menara Siger, upaya memaksimalkan peran yang dapat dijalankan oleh akademisi dalam pengembangan sarana dan prasarana di atraksi wisata Menara Siger, diantaranya adalah menjalin kerjasama dengan berbagai institusi pendidikan dan melibatkan siswa SMK serta mahasiswa di Provinsi Lampung khususnya jurusan Pariwisata. Kerjasama tersebut dapat berbentuk kegiatan teoritis seperti mengadakan penelitian, serta kegiatan praktik dengan mengadakan kegiatan magang.

Selanjutnya upaya untuk memaksimalkan peranan yang dapat dijalankan untuk media dan pengunjung dalam pengembangan sarana dan prasarana di atraksi wisata Menara Siger adalah dengan melaksanakan dan mengikuti aktivitas-aktivitas wisata yang berfokus pada tujuan promosi serta pemasaran di Menara Siger, seperti kompetisi fotografi, mengikuti Festival Budaya Menara Siger dan lain sebagainya. Dengan memanfaatkan internet dan media sosial untuk publikasi, tujuan promosi dan pemasaran di Menara Siger diharapkan dapat tercapai dengan efektif (Turker, dkk., 2016).

Terakhir, adalah upaya memaksimalkan peran juga sangat diperlukan bagi masyarakat lokal dan Pokdarwis Bakauheni, karena mereka adalah pemangku kepentingan yang terdampak langsung maupun tidak langsung terhadap pengembangan pariwisata di daerahnya (Andriotis, 2007; Ardika, 2018). Upaya untuk memaksimalkan peran yang dapat dilakukan oleh masyarakat lokal dan Pokdarwis Bakauheni antara lain yaitu mengikuti sosialisasi, penyuluhan, pelatihan dan kegiatan lainnya yang berfungsi untuk meningkatkan pemahaman kedudukan mereka dalam menjalankan kegiatan-kegiatan yang berhubungan dengan pariwisata di Menara Siger. Dalam konteks pengembangan dan pengelolaan, peningkatan pemahaman sangat diperlukan untuk menyatukan tujuan. Untuk mengimplementasikan kegiatan ini, diperlukan peranan dari pemerintah setempat sebagai fasilitator.

Berkaitan dengan upaya peningkatan pemahaman masyarakat, diperlukan koordinasi Koordinasi yang disarankan adalah koordinasi yang bersifat proaktif dan dapat berjalan dua arah (Altinay, dkk., 2015). Bentuk koordinasinya adalah dengan mengadakan pelatihan-pelatihan dalam berbagai aspek untuk meningkatkan pemahaman masyarakat lokal terhadap pengembangan pariwisata di daerahnya, menyamakan persepsi dengan berbagai pemangku kepentingan, serta terbentuknya implementasi dan sinkronisasi dari kegiatan dan program pengembangan pariwisata di daerahnya. Proses koordinasi juga dapat dilakukan secara formal dan informal, melalui konferensi lengkap, pertemuan berkala, pembentukan panitia gabungan, 
pembentukan badan koordinasi staf, wawancara dengan bawahan, edaran/memo berantai, buku pedoman lembaga, tata kerja dan sebagainya. Selain itu, dalam melaksanakan koordinasi yang bersifat proaktif sebaiknya ada penanggung jawab yang jelas, sehingga diharapkan tidak ada tumpang tindih peran dan tugas diantara para pemangku kepentingan.

\section{Kesimpulan}

Penelitian ini berusaha untuk menganalisis dua persoalan utama, yaitu mengenai identifikasi dan peran pemangku kepentingan, dan model koordinasi yang dilakukan oleh masingmasing pemangku kepentingan tersebut. Pengembangan sarana dan prasarana di atraksi wisata Menara Siger tentu melibatkan pihak-pihak pemangku kepentingan dengan perannya masing-masing, baik secara langsung maupun tidak langsung. Penelitian ini telah berhasil mengidentifikasi pemangku kepentingan yang terlibat terhadap pengembangan sarana dan prasarana di atraksi wisata Menara Siger meliputi: 1) Pemerintah yang berperan dalam menyelenggarakan kegiatan penyediaan dan pengelolaan dana, fungsi-fungsi perumusan dan penetapan kebijakan pariwisata, menyediakan sebagian besar sarana dan prasarana di Menara Siger, mengelola operasional sarana dan prasarana di Menara Siger, fasilitator terhadap pemangku kepentingan yang lain dan menyediakan infrastruktur sosial dan umum untuk meningkatkan kualitas kehidupan masyarakat sekitar; 2) Pengunjung berperan dalam membantu dana operasional kebersihan di Menara Siger; 3) Industri/pelaku usaha berperan dalam menyediakan kebutuhan untuk pengunjung dan masyarakat lokal; 4) Akademisi, berperan dalam membantu perencanaan pengelolaan sarana dan prasarana di Menara Siger; 5) Lembaga nonpemerintah/LSM, berperan dalam membantu mengelola dan meningkatkan mutu sarana dan prasarana di Menara Siger; 6) Media berperan dalam membantu promosi dan pemasaran Menara Siger; dan 7) Masyarakat lokal berperan dalam membantu industri dan pelaku usaha pariwisata untuk penyediaan sarana dan prasarana untuk kebutuhan pengunjung.

Masing-masing pemangku kepentingan tersebut di atas mempunyai peran dan kapasitas masing-masing dalam mengembangkan sarana dan prasarana di Menara Siger Namun demikian, dalam pelaksanaannya masih terdapat pemangku kepentingan yang perannya paling mendominasi diantara pemangku kepentingan lainnya. Pemangku kepentingan yang berperan paling dominan dalam pengembangan sarana dan prasarana di atraksi wisata Menara Siger adalah pihak pemerintah, pihak lembaga nonpemerintah/LSM, dan pihak industri/pelaku usaha pariwisata. Mereka berkuasa dikarenakan kewenangan, peraturan dan kepentingannya masing-masing terhadap pengembangan sarana dan prasarana di Menara Siger.

Penelitian ini juga menunjukkan bahwa kendala yang dialami dalam pengembangan sarana dan prasarana di atraksi wisata Menara Siger, secara umum mengenai belum maksimalnya peran dari masing-masing pemangku kepentingan karena kurangnya komunikasi diantara para pemangku kepentingan yang menyebabkan pemahaman yang tidak jelas terhadap peranan dari masng-masing pemangku kepentingan, serta terlalu banyak intervensi dan dominasi dari pihak pemerintah sehingga menyebabkan terjadinya tumpang tindih peran pemangku kepentingan. 


\section{Rekomendasi}

Untuk meminimalisasi kendala-kendala yang terjadi di Menara Siger, diperlukan upayaupaya untuk memaksimalkan peran masing-masing pemangku kepentingan di Menara Siger, diantaranya sebagai berikut:

1. Selaku pihak yang paling mendominasi, pemerintah sebaiknya memperbanyak kegiatankegiatan sosialisasi, penyuluhan, rapat koordinasi dan kegiatan lainnya yang bertujuan untuk meningkatkan pemahaman dan partisipasi masing-masing pemangku kepentingan. Peningkatan pemahaman sangat diperlukan untuk menyatukan tujuan. Upaya ini dapat diperkuat oleh wewenang pemerintah melalui pembuatan produkproduk hukum mengenai aturan kegiatan yang harus diikuti oleh seluruh pemangku kepentingan.

2. Menjalin kerjasama dengan berbagai institusi pendidikan dan melibatkan siswa SMK serta mahasiswa di Provinsi Lampung khususnya jurusan Pariwisata. Kerjasama tersebut dapat berbentuk kegiatan teoritis seperti mengadakan penelitian, serta kegiatan praktik dengan mengadakan kegiatan magang.

3. Melaksanakan dan mengikuti aktivitas-aktivitas wisata yang berfokus pada tujuan promosi serta pemasaran di Menara Siger, seperti menjalin kerjasama dengan komunitas-komunitas, mengadakan kompetisi fotografi, ikut meramaikan Festival Budaya Menara Siger dan lain sebagainya. Dengan memanfaatkan internet dan media sosial untuk publikasi, tujuan promosi dan pemasaran di Menara Siger diharapkan dapat tercapai dengan efektif.

4. Mengadakan koordinasi yang bersifat proaktif dan dapat berjalan dua arah. Bentuk koordinasinya adalah dengan mengadakan pelatihan-pelatihan dalam berbagai aspek untuk meningkatkan pemahaman masyarakat lokal terhadap pengembangan pariwisata di daerahnya, menyamakan persepsi dengan berbagai pemangku kepentingan, serta terbentuknya implementasi dan sinkronisasi dari kegiatan dan program pengembangan pariwisata di daerahnya. Selain itu, dalam melaksanakan koordinasi yang bersifat proaktif sebaiknya ada penanggung jawab yang jelas, sehingga diharapkan tidak ada tumpang tindih peran dan tugas diantara para pemangku kepentingan.

\section{Daftar Pustaka}

Altinay, L., Paraskevas, A., \& Jang, S. S. 2015. Planning Research in Hospitality and Tourism. Oxford: Elsevier Linacre House.

Andriotis, K. 2007. A Framework for The Tourism Planning Process. Kanishka Publishers: New Delhi.

Ardika, I. G. 2018. Kepariwisataan berkelanjutan: rintis jalan lewat komunitas. Penerbit Buku Kompas.

Badan Pusat Statistik Lampung Selatan. 2020. Kabupaten Lampung Selatan Dalam Angka 2020. Lampung Selatan: Badan Pusat Statistik Lampung Selatan.

Carr, David. 2011. Implication for Tourism Planning and Destination Management. New Delhi: Tilak Wasan.

Cooper, J., Lewis, R., \& Urquhart, C. 2004. Using Participant Or Non-Participant Observation To Explain Information Behaviour. Information Research, 9(4), 9-4.

Dinas Pariwisata dan Ekonomi Kreatif Provinsi Lampung. 2020. Peraturan Gubernur Lampung No. 10 Tahun 2020 Tentang Pembentukan, Organisasi dan Tata Kerja Cabang Dinas dan Unit Pelaksana Teknis Daerah Pada Perangkat Daerah Provinsi Lampung. Telukbetung: Gubernur Lampung. 
Domański, B., \& Gwosdz, K. 2010. Multiplier Effects in Local and Regional Development. Quaestiones Geographicae, 29(2), 27-37.

Donaldson, T., \& Preston, L. E. 1995. The Stakeholder Theory of The Corporation: Concepts, Evidence, and Implications. Academy of Management Review, 20(1), 65-91.

Alonso, A., \& Nyanjom, J. 2017. Local Stakeholders, Role and Tourism Development. Current Issues in Tourism, 20(5), 480-496.

Ellitan, L., \& Anatan, L. 2009. Manajemen Inovasi Transformasi Menuju Organisasi Kelas Dunia. Bandung: Alfabeta.

Freeman, R. E., \& McVea, J. 2001. A Stakeholder Approach to Strategic Management. The Blackwell Handbook of Strategic Management, 189-207.

Gunn, C.A. \& Var, T. 2002. Tourism Planning: Basics, Concepts and Cases, 4th edition, UK: Routledge.

Hieu, A Vu Minh, Rašovská, Ida. 2018. Proposed Model on Stakeholders Impacting on Destination Management as Mediator to Achieve Sustainable Tourism Development. Trendy v podnikání- Business Trends, 8(1), 90-102.

Jordan, E., Vogt, C., Kruger, L., \& Grewe, N. 2012. The Role of Governance in Tourism Planning. University of Massachusetts Amherst.

Kumar, S. P. 2014. Role of Media in The Promotion of Tourism Industry in India. Global Review of Research in Tourism, Hospitality and Leisure Management, 1(3), 187-192.

Kurnianto, Laviehana D. 2019. Kolaborasi Antar-Pemangku Kepentingan Dalam Mewujudkan Program Sustainable Tourism Development di Desa Wisata Pulesari, Wonokerto, Turi, Sleman, Daerah Istimewa Yogyakarta. Skripsi, Fakultas Ilmu Budaya, Universitas Gadjah Mada: Yogyakarta.

Lemmetyinen, A. 2010. Coordination of Cooperation in Tourism Business Networks. Turun School of Economics. Sarja A, 4.

Lewis, D. 2010. Nongovernmental Organizations, Definition and History. International Encyclopedia of Civil Society, 1056-1062.

Makahinda, N., \& Tampongangoy, D. L. 2015. Peran Dinas Pariwisata dalam Pembangunan Industri Pariwisata Kota Bitung. Jurnal Administrasi Publik, 3(31), 87-101.

Malone, T. W. 1988. What is Coordination Theory? In National Science Foundation Coordination Theory Workshop: Cambridge, Massachusetts.

Manish, R. 2007. Tourism Planning and Development. New Delhi: Rajat Publication, 25.

Miles, M. B., dan Huberman, A. M. 1984. Qualitative Data Analysis: A Sourcebook of New Methods. California: Sage Publications.

McKercher, B. 2003. Sustainable Tourism Development-Guiding Principles for Planning and Management. In National Seminar on Sustainable Tourism Development (hal. 5-9).

Narendra, W. 2018. Identifikasi Kebutuhan Sarana dan Prasarana Wisata Berdasarkan Persepsi Pengunjung di Pantai Sipelot Kabupaten Malang. Disertasi, Institut Teknologi Nasional Malang.

Pemerintah Daerah Provinsi Lampung. 2008. Surat Keputusan Gubernur Lampung No:G/493/II.02/HK/2008 Tentang Pembentukan Pengelola dan Pengembangan Kawasan Wisata Menara Siger No. 493 Tahun 2008. Telukbetung: Gubernur Lampung.

Pemerintah Daerah Provinsi Lampung. 2008. Surat Keputusan Gubernur Lampung No: G/610/B.IV/HK/2009 Tentang Pembentukan Pengelola dan Pengembangan Kawasan Wisata Menara Siger No. 610 Tahun 2009. Telukbetung: Gubernur Lampung. 
Pemerintah Kabupaten Lampung Selatan. 2012. Peraturan Daerah Kabupaten Lampung Selatan No. 15 Tahun 2012 Tentang Rencana Tata Ruang Wilayah Kabupaten Lampung Selatan Tahun 2011-2031. Kalianda: Sekretaris Daerah Kabupaten Lampung Selatan.

Pemerintah Provinsi Lampung. 2019. Rencana Pembangunan Jangka Menengah Daerah Provinsi Lampung Tahun 2019-2024. Lampung: Sekretaris Daerah Provinsi Lampung.

Pemerintah Republik Indonesia. 2014. Peraturan Menteri Komunikasi dan Informatika Republik Indonesia No. 32 Tahun 2014 Tentang Persyaratan dan Tata Cara Pemberian Izin Penyelenggaraan Pos. Jakarta: Kementerian Komunikasi dan Informatika Republik Indonesia.

Pemerintah Republik Indonesia. 2016. Peraturan Pemerintah Republik Indonesia No. 47 Tahun 2016 Tentang Fasilitas Pelayanan Kesehatan. Jakarta: Kementerian Sekretariat Negara Republik Indonesia.

Presiden Republik Indonesia. 2009. Undang-Undang Republik Indonesia No. 10 Tahun 2009 Tentang Kepariwisataan. Jakarta: Kementerian Sekretariat Negara Republik Indonesia.

Richards, G. 2002. Tourism Attraction Systems: Exploring Cultural Behavior. Annals of Tourism Research, 29(4), 1048-1064.

Rodríguez, X. A., Martinez-Roget, F., \& Pawlowska, E. 2013. Academic Tourism: A More Sustainable Tourism. Regional and Sectoral Economic Studies, 13(2), 89-98.

Stange, J., \& Brown, D. 2013. Tourism Destination Management Achieving Sustainable and Competitive Results. US Agency for International Development: Washington.

Swarbrooke, J. 1999. Sustainable Tourism Management. Cabi.

Tang, C. H. H., \& Jang, S. S. 2009. The tourism-economy causality in the United States: A sub-industry level examination. Tourism Management, 30(4), 553-558.

Turker, N., Alaeddinoglu, F., \& Can, A. S. 2016. The Role of Stakeholders in Sustainable Tourism Development in Safranbolu, Turkey. In 2016 International Conference on Hospitality, Leisure, Sports, and Tourism (pp. 415-426). Jepang: Chiba Institute of Technology.

United Nations Environment Programme, Division of Technology, Economics, Production, Consumption Unit. 2003. A Manual for Water and Waste Management: What the Tourism Industry Can Do To Improve Its Performance. United Nations Environment Programme.

United Nations Environment Programme, Division of Technology, \& Economics. 2005. Making Tourism More Sustainable: A Guide for Policy Makers. World Tourism Organization Publications.

United Nations World Tourism Organization. 2013. Sustainable Tourism for Development Guidebook. World Tourism Organization. European Commission, Madrid.

World Tourism Organization. 2005. Making Tourism More Sustainable. https://www.eunwto.org/doi/pdf/10.18111/9789284408214. Diakses pada 4 Mei 2020. 